\title{
Artikkeli
}

\section{Suomi24-keskustelut kohtaamisten ja törmäysten tilana}

Artikkelissa tarkastellaan Suomi24-foorumikeskusteluita käyttäjien välisen kohtaamisen ja vuorovaikutuksen tilana keskustelukulttuurin ja vallankäytön näkökulmista. Tutkimusaineistona on vuonna 2016 Citizen Mindscapes -hankkeessa toteutetun käyttäjäkyselyn avovastausaineisto, jossa käyttäjät kuvaavat foorumikeskustelujen herättämiä positiivisia ja negatiivisia tunteita sekä pohtivat, mitä heidän elämästään puuttuisi, jos Suomi24-foorumia ei olisi. Käyttäjät kokivat keskustelujen asiattomuuden ja häiriköinnin raskaaksi ja haluaisivat siksi moderoijien puuttuvan nykyistä tehokkaammin asiattomaan keskusteluun. Omina vaikutusmahdollisuuksinaan käyttäjät näkevät lähinnä sietokyvyn kasvattamisen tai foorumilta poistumisen. Asiattoman keskustelun vastapainoksi rakentuu kuitenkin käyttäjien kokemus foorumin yhteisöllisyydestä, muilta keskustelijoilta saadusta vertaistuesta ja kokemusperäisen tiedon löytämisestä. Suomi24-keskustelut näyttäytyvät näin käyttäjilleen monipuolisen vuorovaikutuksen mahdollistavana tilana, jota trollien ja muiden keskustelun hämmentäjien toiminta tuhoaa.

AVAINSANAT: sosiaalinen media, verkkokeskustelu, käyttäjäaineisto, Suomi24

$\mathrm{V}$ erkkokeskusteluja koskeviin luonnehdintoihin törmää arjen keskusteluissa, journalistisissa teksteissä ja poliitikkojen puheenvuoroissa. Verkkokeskustelu on joskus synonyymi Facebookin ryhmissä tai yksityisten ihmisten seinällä käytävään keskusteluun, joskus sillä viitataan uutiskommenteissa esitettyihin näkemyksiin ja toisinaan keskustelufoorumien keskusteluketjuihin. Asiayhteydestä riippuen verkossa käyty keskustelu näyttäytyy arvokkaana kansalaismielipiteenä, nettikansan kohtaamisissa syntyneinä uusina ideoina ja ilmiöinä tai ala-arvoisena törkynä.

Sosiaalisen median vuorovaikutuksesta puhuttaessa viitataan usein sosiaalisen median kupliin (echo chambers, Pariser 2011), joita Facebookissa ja muissa verkosto- 
palveluissa syntyy samanmielisten kesken. Kun ihmiset verkostoituvat lähinnä itsensä kaltaisten, samanlaisen sosiaalisen taustan ja arvomaailman jakavien kanssa, tässä vuorovaikutuksessa heidän jo olemassa olevat näkemyksensä vahvistuvat. Lisäksi heille muotoutuu kuva todellisuudesta, joka saattaa poiketa huomattavasti toisenlaiset taustat omaavien käsityksistä. (Seppänen \& Väliverronen 2013, 212-213; Sunstein 2001, 58-59; Mikal ym. 2014.) Toisaalla verkon käyttäjät taas kohtaavat toisensa hyvinkin näkyvästi ja kärjekkäästi, erityisesti kun keskusteluja seuraa ja niihin osallistuu näkemyksiltään kirjava ihmisjoukko (Paasonen 2014, 23).

Tässä artikkelissa tarkastelen Citizen Mindscapes -tutkimushankkeessa' tehdyn käyttäjäkyselyn pohjalta Suomi24-keskusteluja tilana, joka saattaa arjessaan etäällä toisistaan olevat inmiset tekemisiin toistensa kanssa. Suomi24-palvelussa on suosittu keskustelufoorumi, joka perustuu vähemmän oman identiteetin rakentamiseen tai kaveriverkostoihin kuin Facebookin kaltaiset sosiaalisen median verkostopalvelut. Facebookiin, Twitteriin tai moniin keskustelufoorumeihinkin verrattuna Suomi24:n tarjoama käyttäjäkokemus tuntuu vanhanaikaiselta, jopa toimimattomalta. Esimerkiksi kännykällä selattaessa keskustelujen luettavuus ja navigoitavuus eivät toimi sujuvasti, sillä foorumia ei ole optimoitu mobiililaitteille (Lagus ym. 2016, 8). Foorumia voisi siten kuvata vähemmän kehittyneeksi tilaksi (less developed space), jota ulkopuolelta katsotaan väheksyen ja jossa anonyymi keskustelun koetaan elävän villinä ja hallitsemattomana (vrt. Pratt 2008 [1992], xiii). Sosiaalisen median sisällä on erilaisia alustoja, joista osaa - kuten keskustelupalstoja, kuvalautoja ja vertaisverkkoja - ei helposti mielletä sosiaaliseksi mediaksi, koska ne ikään kuin sotivat sosiaalisen median jonkinlaista ideaalikäyttöä vastaan mauttomalla, arkisella tai laittomalla sisällöllään (Suominen 2013, 287). Käyttäjäkyselyn perusteella Suomi24-keskusteluissa on tällaisia piirteitä.

Aluksi pohdin, millainen keskustelutila Suomi24-foorumi on ja millaiseksi sen keskustelukulttuuri on rakentunut. Analysoin tämän jälkeen yksityiskohtaisemmin vuorovaikutuksen myönteisiksi ja kielteisiksi koettuja piirteitä, sekä millaista on anonyymien keskustelujen hallinnointi ja käyttäjille rakentunut toimijuus. Luen käyttäjäkyselyn avovastauksia kuvauksina käyttäjien kohtaamisista Suomi24:n kulttuurisessa tilassa. Tutkimuskysymykseni ovat seuraavat:

- Millaisia piirteitä käyttäjät liittävät foorumikeskusteluun, itseensä käyttäjinä ja muihin keskustelijoihin?

- Miten käyttäjät arvioivat moderointikäytäntöjä ja niiden merkitystä keskustelulle?

- Mikä on Suomi24-keskusteluiden mahdollistaman anonyymin kirjoittamisen merkitys käyttäjille?

- Mitä päätelmiä käyttäjien vastausten perusteella voi tehdä Suomi24-foorumin luonteesta keskustelun tilana? 


\section{Keskustelufoorumit kohtaamisten kontaktivyöhykkeinä}

Keskustelufoorumeita on tutkittu erityisesti julkisen keskustelun tiloina. Yhteiskunnallista keskustelua syntyy myös muille kuin poliittisten aiheiden käsittelyyn tarkoitetuille foorumeille, samoin kuin muihin sosiaalisen median verkostoihin, kuten Twitteriin ja Facebookiin, joissa ihmiset puivat arkeaan ja yksityiseen elämänpiiriinsä liittyviä aiheita (esim. Papacharissi 2004; Renninger 2015; Sobkowicz \& Sobkowicz 2012; Svensson 2015; Graham ym. 2016; Freelon 2015; Graham \& Harju 2011). Journalismin kylkeen keskusteluja viriää sanomalehtien yleisönosastojen lisäksi verkkouutisten kommenttiosioihin (esim. Reader 2012; Kangaspunta 2016; McCluskey \& Hmielowski 2011). Verkkokeskustelujen mahdollistamaa yhteisöllisyyttä ja osallistumista on tutkittu etenkin johonkin tiettyyn aihepiiriin, esimerkiksi terveyteen tai harrastuksiin keskittyvillä foorumeilla, keskustelujen aggressiivisuutta ja vihapuhetta on analysoitu erityisesti maahanmuuttokeskustelujen yhteydessä (Pöyhtäri ym. 2013; Malinen 2015, 230; Rowe 2015; Milner 2013; Nikunen 2010). Keskustelijoiden tunnereaktiot muokkaavat keskustelua ja keskusteluiden tunneintensiteetti osaltaan kiinnittää käyttäjiä sosiaalisen median alustoihin, keskusteluketjuihin ja ryhmiin. (Nikunen \& Pantti 2017; Paasonen 2014.) Suomi24-käyttäjäkyselyn vastausten avulla on mahdollista hahmottaa käyttäjien kokemuksia näistä vuorovaikutuksen muodoista.

Keskustelufoorumit antavat mahdollisuuden pysytellä tunnistamattomana ja sen myötä tilan sellaistenkin tunteiden ja asioiden ilmaisemiseen, joiden esiin tuominen kasvokkaisessa vuorovaikutuksessa tai muuten tunnistettavasti olisi sosiaalisesti mahdotonta. Sosiaaliset verkostosivustot puolestaan tarjoavat kotoista oleskelua, näennäistä yksityisyyttä ja mahdollistavat oman elämän julkisen esittämisen tavalla, joka voi antaa käyttäjälle vaikutelman siitä, ettei hän kommunikoi muukalaisten kanssa vaan kertoo kuulumisia ystäville ja tuttaville vapaasti, kenenkään hallinnoimatta ja valvomatta (Ridell 2011, 23; Hirschkind ym. 2017, 7). Verkostopalveluiden kotoisuuteen verrattuna anonyymit keskustelufoorumit ovat kuin suurkaupungin katuja, joilla voi törmätä hyvin monenlaisiin kulkijoihin. Niissä myös valvonta on ajoittain hyvinkin näkyvää moderaattorien puuttuessa keskustelun kulkuun viestejä ja keskusteluketjuja poistamalla tai keskustelun pelisäännöistä muistuttamalla. Tässä mielessä keskustelufoorumeja voidaan pitää tiloina, joissa käyttäjät ovat oman kuplansa ulkopuolella ja kohtaavat heille vieraita näkemyksiä. Näissä kohtaamisen tilanteissa piilee mahdollisuus näkemysten muuttumiseen, mutta myös yhä syvemmälle omien mielipiteiden muodostamiin poteroihin kaivautumiseen. Kummassakin tapauksessa käyttäjä tulee tiedostaneeksi toisenlaisten näkemysten olemassaolon ja joutuu muodostamaan suhtautumisensa niihin.

Kimmokkeen tarkastella Suomi24-keskusteluita tällaisena kohtaamisen tilana antoi Mary Louise Pratt, joka on käyttänyt kontaktivyöhykkeen käsitettä tutkiessaan matkakirjoittelua Euroopan siirtomaaisännyyden ja siihen liittyvän merkityksenannon dynamiikan näkökulmista. Kontaktivyöhyke käsitteenä liittyy kolonialismiin, siirtomaiden alkuperäisväestön ja siirtomaaisäntien kulttuurien kohtaamiseen, mutta se on myös kulttuurinen tila, jossa historiallisesti ja maantieteellisesti erillään eläneet ihmiset ja 
kulttuurit joutuvat tekemisiin toistensa kanssa. Kontaktivyöhykkeellä tapahtuvissa kohtaamisissa ovat läsnä valtasuhteet, eriarvoisuus ja kohdattujen näkeminen 'toisina'. Suomi24-kyselyn vastauksissa esiintyi runsaasti puhetapaa, jossa vastaaja näki muut käyttäjät huonossa valossa ja samalla asemoi itsensä tämän moittimansa kirjoittajajoukon ulkopuolelle. Kontaktivyöhykkeen käsitteen avulla on mahdollista tarkastella toimijoiden rakentumista, (valta)suhteita ja vuorovaikutusta. (Pratt 2008 [1992], 4-7; ks. myös Hall 2003, 105-111.)

Internetin julkisessa tilassa tapahtuva toiminta saa varsinaisen merkityksensä ihmisten läsnäolosta ja kanssakäymisestä. Tila myös muuttaa muotoaan, kun toiminta tilassa muuttuu. (Ridell ym. 2009, 9.) Toiminta ei siten ole irrallaan verkkotilan rakenteista, ja myös ihmisten toiminta rakentaa verkkotilaa esimerkiksi vetämällä sinne lisää käyttäjiä (Ridell 2011, 25). Keskustelusta tulee omanlaistaan erilaisissa verkkotiloissa, vaikka keskustelijat olisivatkin ainakin osittain samoja näillä eri foorumeilla (Renninger 2015, 1514). Foorumien tekniset ominaisuudet, moderointi ja kirjoittajien tunnistautumiskäytännöt vaikuttavat myös käytyyn keskusteluun (McCluskey \& Hmielowski 2011; Sobkowicz \& Sobkowicz 2012). Tässä artikkelissa tarkastelun ulkopuolelle jäävät taloudellis-teknologiset valtasuhteet. Ne ovat kyllä läsnä Suomi24-foorumin verkkotilassa, mutta jäävät näkymättömiksi käyttäjille, eivätkä siten tule kyselyaineistossa sanallistuiksi. Avovastausaineistossa valta nousee esiin moderaattorien harjoittaman foorumin hallinnoinnin muodossa. Keskustelijoiden harjoittamaa vallankäyttöä puolestaan on esimerkiksi keskusteluiden tai toisten käyttäjien häiriköinti.

\section{Aineisto ja menetelmät}

Citizen Mindscapes -hankkeessa toteutettiin verkkokysely Suomi24-keskustelufoorumin käytöstä sekä siihen liittyvistä kokemuksista ja tuntemuksista. Kyselyn linkki oli esillä Suomi24-keskustelualueilla ja kyselyyn saattoi vastata kahden viikon ajan joulukuussa 2016. Tänä aikana kyselyn avasi vajaa 4500 käyttäjää, joista kyselyyn vastasi noin 1400 henkeä. Vastaajia pyydettiin määrittelemään, ovatko he satunnaisia vierailijoita, keskusteluiden lukijoita vai keskusteluihin osallistuvia kirjoittajia ${ }^{2}$. Tämä oli ainoa pakollinen kysymys. Satunnaisiksi vierailijoiksi itsensä luokitelleilta kysyttiin pelkkiä taustatietoja, muut vastasivat lisäksi muun muassa kysymyksiin foorumin käyttökokemuksista sekä keskustelun laadusta ja merkityksestä käyttäjille. Tässä artikkelissa viittaan termillä käyttäjä sekä keskusteluihin osallistuviin kirjoittajiin, että keskusteluja pelkästään seuraaviin eli lukijoihin. Sanoilla keskustelija ja kirjoittaja tarkoitan keskusteluihin osallistuvia. (Vrt. Malinen 2015, 231.)

Kyselyyn vastanneista hahmottuu niin sanotuksi peruskäyttäjäksi kaupungissa asuva keski-ikäinen mies, joka asuu yhdessä avio- tai avopuolisonsa kanssa. Lapsia ei ole tai he ovat jo muuttaneet kotoa. Yksin asuvia vastaajista oli reilu kolmannes. Miehiä oli vastanneista enemmistö ja ikäjakauma painottui keski-ikäisiin; nuoria oli vastaajien joukossa vähemmän (ks. kuvio 1). Eläkkeellä oli kolmasosa vastaajista. Joka 
kymmenes vastaaja oli kyselyyn vastatessaan työtön. Keskustelufoorumien keskustelijajoukko on usein miesvaltaista, sen sijaan ikäjakauma on erilainen eri foorumeilla (Pöyhtäri ym. 2013, 208-209).

Kuvio 1: Vastaajien ikä- ja sukupuolijakaumat ( $\mathrm{N}=1271)$.

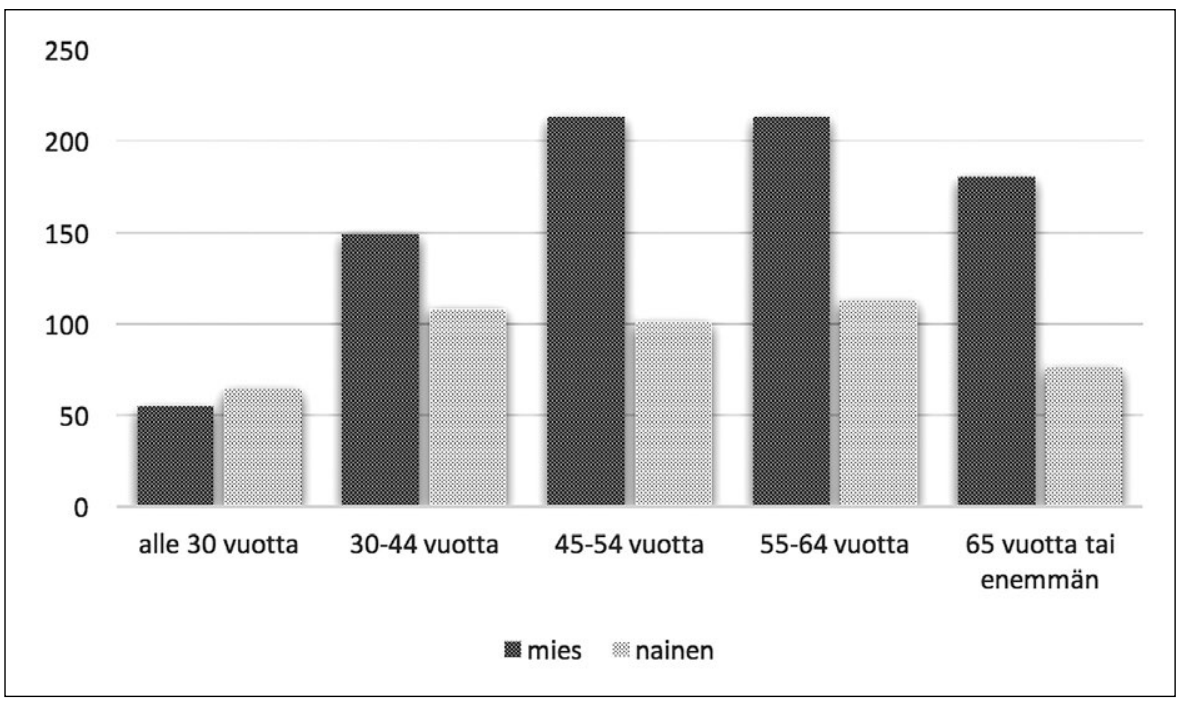

Avoimessa internetkyselyssä vastaajat ovat valikoituneet, joten näyte ei edusta koko käyttäjäkuntaa. Vastaamaan motivoituneiden joukossa on aktiivikäyttäjiä, jotka ovat kiinnostuneita foorumista ja siten innokkaita kertomaan siitä näkemyksiään. Kirjoittajien osuus korostuukin suhteessa muihin foorumin käyttäjiin. Vastaajista 39\% oli satunnaisia kävijöitä, $17 \%$ lukijoita ja $44 \%$ foorumille kirjoittavia. Kirjoittajilla on usein tiiviimpi suhde foorumiin ja sen keskusteluihin kuin pelkässä lukijaroolissa pysyttelevillä. Näin kirjoittajat olivat todennäköisesti hieman innokkaampia vastaamaan kuin muut Suomi24-käyttäjät.

Citizen Mindscapes -hankkeessa Suomi24-keskustelua tarkastellaan tunneaaltoina, jotka voivat vaimentua tai vahvistua. Hankkeen tutkimuksellinen painopiste on tunnepuheen tuottamisen mekanismeissa. (Lagus ym. 2015; Pink ym. 2018, 6-8.) Tämän tunnepuheeseen kiinnittyvän metodisen näkökulman vuoksi käyttäjäkyselyssä oli kolme avokysymystä, joissa vastaajia pyydettiin kertomaan Suomi24-foorumilla kokemistaan positiivisista ja negatiivisista tunteista sekä pohtimaan, mitä heidän elämästään jäisi puuttumaan, jos keskustelufoorumia ei olisi. Avovastausten muodostamasta aineistosta tuli sekä määrällisesti että sisällöllisesti rikas. Kuhunkin avokysymykseen vastasi noin 500-600 käyttäjää, suurin osa lyhyesti muutaman sanan tai lauseen verran, varsin moni kuitenkin pidemmin. 
Aineistosta välittyi kokemus osallisuudesta Suomi24-keskusteluihin ja tarve vaikuttaa foorumin toimintaan, mutta myös tunne yhteisen foorumin muuttumisesta: mukava keskustelupaikka on mennyt pilalle. Näistä aineistolähtöisistä havainnoista rakentui tämän artikkelin teoreettinen viitekehys keskustelufoorumista tilana ja tilan hallintaan ja vuorovaikutukseen liittyvästä vallankäytöstä.

Verkkokyselyn avulla voi tavoittaa internetin käyttötapoja sekä käyttäjien kokemuksia (Kozinets 2015, 57; Ridell 2011, 27-28). Käyttäjät toivat esiin paitsi keskusteluiden synnyttämiä tunteita, myös monenlaisia verkkokeskusteluun liittyviä ilmiöitä: He puhuivat vihapuheesta, trollaamisesta ja moderoinnista. He määrittelivät keskustelufoorumin erilaisia käyttötarkoituksia ja -tapoja ajankulusta ja viihtymisestä yhteiskunnalliseen keskusteluun ja tiedonhakuun. He vertailivat Suomi24-keskusteluita muihin mediasisältöihin, kuvailivat värikkäin adjektiivein muita käyttäjiä tai asemoivat itsensä ja ajatuksensa suhteessa foorumin keskusteluihin.

Avovastaukset koodattiin aineistolähtöisesti rakentuneen temaattisen koodausrungon avulla ATLAS.ti-ohjelmalla. Tätä artikkelia varten analysoitujen aineistoluokkien joukossa oli kolme suurimmaksi muodostunutta luokkaa: puhe keskustelun laadusta, tunnereaktioista ja toisista käyttäjistä. Vuorovaikutukseen liittyvän vallankäytön analysoimiseksi mukana on lisäksi keskustelun häiriköintiä, moderointia ja anonymiteettia koskeva aineisto, sekä vastaajien luonnehdinnat itsestään (ks. taulukko 1). ${ }^{3}$ Avovastaus saattoi tulla koodatuksi useampaan luokkaan, esimerkiksi puhe keskustelun häirinnästä tai moderoinnista liittyi monesti puheeseen keskustelun laadusta ja vastaukset tulivat siten koodatuiksi molempiin luokkiin. Artikkelissa on lisäksi käytetty kyselyn määrällisten kysymysten tuottamaa tietoa vastaajien taustoista, keskustelufoorumin käyttösyistä ja keskustelukulttuurista.

Taulukko 1: Koodausrungon aineistoluokat ja luokkiin koodattujen avovastausten määrä.

\begin{tabular}{|l|l|}
\hline Koodausrungon aineistoluokka & Mainintojen lukumäärä \\
\hline keskustelun laatu & 316 \\
\hline minä keskustelijana (mitä vastaaja kertoo itsestään) & 100 \\
\hline moderointi & 107 \\
\hline muut käyttäjät (viittaukset muihin keskustelijoihin) & 212 \\
\hline nimettömyys, nimimerkin käyttö ja rekisteröityminen & 69 \\
\hline trollaus, häiriköinti ja kiusaaminen & 161 \\
\hline tunnereaktiot keskustellessa tai keskusteluja lukiessa & 256 \\
\hline
\end{tabular}


Analyysi tuo esiin ne tulkinnat, joita käyttäjät tekevät keskusteluista ja muista käyttäjistä kokemustensa pohjalta. Nämä tulkinnat eivät välttämättä aina vastaa todellisuutta, sillä foorumin tekniset ratkaisut, moderaattoreiden valintojen pohjalla olevat perustelut tai muiden käyttäjien motiivit eivät useinkaan tule käyttäjien tietoon. Esimerkiksi keskusteluketjujen katoamisessa ei aina ole kysymys moderoinnista vaan vaikkapa häiriöstä foorumin toiminnassa, eikä satojen häiriöviestien takana ole ehkä sittenkään yksittäinen häiriköivä käyttäjä vaan spämmibotti tai muu palvelua häiritsevä hyökkäys (ks. myös Lagus ym. 2016, 23).

Suomi24 on keskustelufoorumina laaja, se rakentuu useasta temaattisesta keskustelualueesta, jotka jakautuvat vielä hierarkkisesti pienempiin alatasoihin ${ }^{4}$. Näiden sisään sijoittuvat varsinaiset keskusteluketjut. Foorumin keskustelualueille on muodostunut hyvin erilaisia yhteisöjä omine keskustelukäytäntöineen. Osassa keskustelualueita on hyvinkin tiivis käyttäjäyhteisö, toisiin ei niinkään kiinnitytä yhteisön jäsenenä vaan ennemminkin piipahdetaan lukemassa tai kirjoittamassa. Näin foorumi voi näyttää hyvinkin erilaiselta keskusteluympäristöltä eri käyttäjille riippuen siitä, millä keskustelualueilla käyttäjä vierailee ja mitä keskusteluketjuja hän lukee. Foorumilla on myös pitkä historia, keskusteluja on käyty jo lähes kaksikymmentä vuotta. Keskustelut ovat käyttäjäkuntineen, aiheineen ja teknisine ominaisuuksineen muuttuneet vuosien saatossa. (Lagus ym. 2016, 5-10.) Tämä historia ei varsinaisesti piirtynyt näkyväksi kyselytutkimuksen vastauksissa. Kauan keskusteluissa mukana olleet saattoivat vastatessaan muistella keskusteluja pitkän ajan takaa, tuoreempi foorumin käyttäjä sen sijaan perustaa näkemyksensä havainnolleen nykytilaisesta keskustelusta. Joillakuilla vastanneista saattoi olla vastaushetkellä mielessä hyvinkin tuore yksittäinen keskustelukokemus.

\section{Suomi24:n keskustelutila ja keskustelukulttuurin piirteet}

Keskustelufoorumeilla ja niillä käydyillä keskusteluilla on käyttäjilleen moninaisia merkityksiä ja käyttökokemuksia. Niissä haetaan seuraa, vertaistukea, tietoa ja käydään kauppaa tavaroilla ja palveluilla. Keskusteluissa koetaan niin ilon ja mielihyvän kuin erimielisyydenkin tunteita, ideoidaan ja suunnitellaan, käydään älyllistä keskustelua ja juorutaan. (Rheingold 1993, 3.)

Nimimerkkien käyttö ja valittavissa oleva mahdollisuus rekisteröidä nimimerkki vain omaan käyttöön luo puitteet, joissa verkon sosiaalisuus voi muodostua, kasvaa ja kehittyä. (Sobkowicz \& Sobkowicz 2012, 449.) Tapanamme on ottaa tilalliset järjestykset itsestäänselvyyksinä, vaikka tilojen luonne on ratkaisevaa niissä ihmisten välille syntyvän kanssakäymisen ja viestinnän kannalta. Erityisesti verkkotilojen rakentuminen ja niiden vaikutus käyttäjien toimintaan on vaikeasti hahmotettavissa. Verkkotilojen synnyttämä uudenlainen sosiaalisuus pelisääntöineen - ja niiden puuttumisineen - ei myöskään aina kitkatta sovitu osaksi käyttäjien toimintaa. (Ridell 2011, 24.)

Selkeimmin keskustelufoorumin tilallinen luonne nousi esiin Suomi24-käyttäjäkyselyn avovastauksissa silloin, kun vastaajat moittivat keskustelufoorumin käytet- 
tävyyttä. Voikin ajatella, että verkkotila ja sen vuorovaikutusta ohjaavat puitteet tulevat helpoiten näkyväksi silloin, kun palvelun ominaisuudet estävät tai hankaloittavat käyttäjien mielessä olleen toiminnan toteuttamisen: foorumilla navigoinnin, tiedon löytämisen, keskusteluun osallistumisen, viestien lukemisen. Vastauksissa nostettiin ongelmallisina esiin paitsi teknologiset ratkaisut (muun muassa mainosten sijoittuminen, määrä ja sisältö, keskusteluketjujen ja viestien rakenteelliset ominaisuudet), myös keskustelukulttuurin ongelmat ja moderoinnin tehottomuus.

Vastauksissa näkyi inmetys ja närkästys siitä, millaiseksi foorumin keskustelukulttuuri on muodostunut. Avovastauksissa käyttäjät pääsivät kuvailemaan keskusteluja omin sanoin, keskustelun laatua mittaavien kysymysten (ks. kuvio 2) lisäksi. Osassa avovastauksista muisteltiin ja kaivattiin aiempaa, parempaa vuorovaikutusta. Vastauksissa yhtäältä kiiteltiin sanomisen vapauden mahdollistamista, toisaalta toivottiin tiukempaa moderointia.

Kuvio 2: Vastaajien näkemys Suomi24-keskusteluista ( $\mathrm{N}=826-833)$.

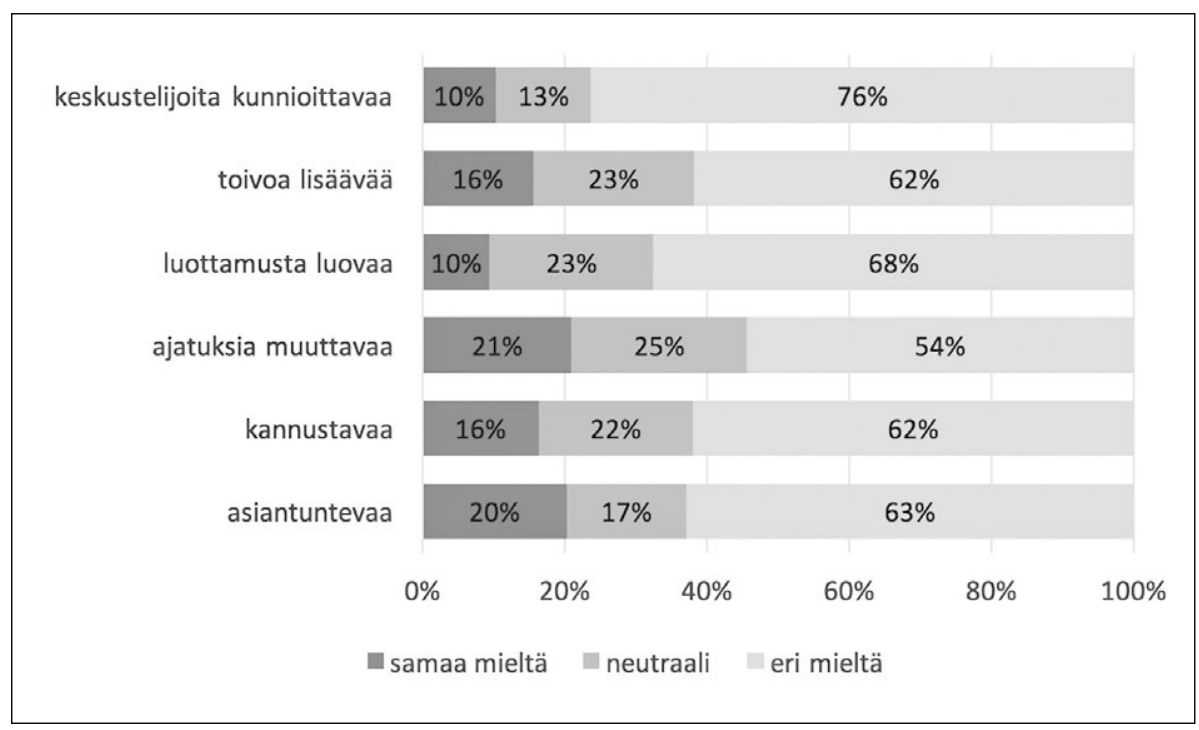

Vastaajien mielestä tietynlainen vuorovaikutus oli keskusteluissa toivottua ja keskustelua edistävää, kun taas osa kommunikaatiosta oli häiritsevää ja foorumikeskusteluja pilaavaa. Vaikka foorumi tarjoaa paikan näkemysten vaihtamiseen ja mahdollisuuden sellaisten ihmisten kohtaamiseen, joita keskustelijat eivät ehkä arjessaan muualla tapaa, keskustelua leimaavat myös monenlaiset kielteiset piirteet henkilökohtaisuuksiin menevästä kommentoinnista aina asioiden vääristelyyn ja vihanlietsontaan.

Käyttäjien esiin nostamat keskustelukulttuurin kielteiset piirteet eivät ole vain Suomi24-keskusteluille ominaisia, vaan keskustelufoorumien ongelmat ovat paljolti samanlaisia kaikkialla. Ongelmia aiheuttaa sääntöjä noudattamattomien keskusteli- 
joiden harvalukuinen joukko, joiden viestejä, esimerkiksi kunnianloukkauksia, laittomia uhkauksia ja kansanryhmää vastaan kiihottamisia joudutaan moderoimaan pois. (Pöyhtäri ym. 2013, 229; Rowe 2015.)

Käyttäjien vastauksissa Suomi24-foorumia kuvataan kuitenkin myös tutuksi ja turvalliseksi. Vastanneista huomattava osa on viihtynyt keskusteluissa kauan: lähes puolet vastaajista on käyttänyt foorumia kymmenen vuotta tai kauemmin. Keskustelufoorumit voidaan nähdä yhteisöinä, joissa yhtäältä viestitään vuorovaikutuksen ja keskustelun ilosta ja jotka toisaalta toimivat välineinä keskustelijoille kulloinkin ajankohtaisen informaation hankkimiseksi (Rheingold 2008 [1987]; Baym 2010, 84-85; Jenkins 2006, 27; Massanari 2015, 23-24; Matikainen 2008, 33). Suomi24-keskustelut esitetään vastauksissa myös paikaksi, joka ei edusta "virallista totuutta" tai asiantuntijatietoa vaan tarjoaa käyttäjien kokemusmaailmasta ja tietämyksestä ponnistavaa, käyttäjien itselleen arvokkaaksi mieltämää tietoa. Tästä näkökulmasta foorumilla keskustelevat näyttäytyvät omaan elämänkokemukseensa nojaavina yksilöinä (ks. myös Vainikka, tulossa). Verkkokeskusteluissa henkilökohtaisilla kokemuksilla on keskeinen rooli, niitä voidaan esittää muille julkisesti ja niiden pohjalta voi esittää omia tulkintoja asioista ilman, että viestin lähettäjän tarvitsee perustella kokemustensa yleistä kiinnostavuutta - toki keskustelussa hänen kokemuksensa voivat joutua tällaisenkin arvioinnin kohteeksi (Arpo 2005, 296).

Suomi24-keskustelujen koettiin myös edustavan kansan ääntä, antavan tilaa sellaiselle kansalaiskeskustelulle, jonka käyttäjät eivät nähneet pääsevän ääneen muissa mediatiloissa. Osalle tämä kansan ääni toi totuuden ("kyllä kansa tietää"), toiset vastaajat taas eivät jakaneet käsitystä totuudellisuudesta mutta korostivat sitä, miten he saivat keskusteluista tietoa toisin ajattelevien näkemyksistä. Näiden vastausten perusteella keskusteluissa erilaiset ihmiset ja näiden maailmankuvat todella tulivat törmäytetyiksi. Seuraavissa osioissa käsittelen yksityiskohtaisemmin Suomi24-keskustelutilan vuorovaikutuksen myönteisiä ja kielteisiä piirteitä sekä analysoin, millaiseksi käyttäjät kokevat tilan hallinnoinnin sekä omat vaikutusmahdollisuutensa keskustelun muotoutumiseen.

\section{Vuorovaikutuksen anti: viihdettä, vinkkejä ja vertaistukea}

Suomi24 on ollut keskeisellä paikalla suomalaisten verkkokeskustelujen kartalla jo toistakymmentä vuotta. Mitkä asiat saavat käyttäjät tulemaan Suomi24-palveluun, keskusteluja lukemaan ja niihin osallistumaan?

Foorumilla keskustelevien ja pelkiksi lukijoiksi tunnustautuvien vastaajien foorumin käytön syyt poikkesivat osin toisistaan. Kyselyn perusteella kirjoittajat kokivat foorumin käytön kolmeksi tärkeimmäksi syyksi ajan kuluttamisen, uuden tiedon etsinnän ja asioiden ja tapahtumien ihmettelyn. Lisäksi varsin moni kirjoittajista myös kommentoi uutisia ja auttoi muita keskustelijoita, esimerkiksi jakamalla tietoa ja kokemuksia sekä toimimalla tukena muille. Lukijaroolissa pysytteleville nämä viimeksi mainitut aktiivisen osallistumisen ulottuvuudet eivät ymmärrettävästi nousseet 
tärkeiksi, sen sijaan ajan kuluttaminen oli heillekin merkittävin foorumin käytön syy.

Vastaajissa oli myös niitä, jotka seurasivat keskusteluja yhteiskunnallisesta tai työhön liittyvästä motiivista:

Suomi24:n kautta näkee läpileikkauksen suomalaisista ja ulottuu sellaiseen kansanosaan, jota ei koskaan ole ollut omassa sosiaalisessa tai työelämässä ennen. (Mies, 65- )

Tietyn, pienen kansanosan ahtaaseen maailmannäkemykseen kurkistaminen. Joka siis tapahtuu työn takia. (Nainen, 55-64)

Lähinnä ammattini puolesta seurailen, mitä työhöni liittyvää keskustelua maallikot täällä käyvät, jotta osaa reagoida uskomuksiin oikein. (Nainen, 30-44)

Avovastauksissa käyttäjät paitsi pohtivat keskusteluiden myönteisiä ja kielteisiä piirteitä, myös luonnehtivat siinä samalla itseään monin tavoin. Osa vastaajista kuvaili itseään paksunahkaiseksi keskustelijaksi, joka ei loukkaannu eikä ota tosissaan räväköitäkään keskusteluja. Nämä vastaajat nauttivat väittelyistä tai seurailevat keskusteluja viihteenä.

Rääväsuisten ja nimittelevien vastausten saaminen harmittaa joskus, koska olen odottanut saavani taidokkaampaa väittelyä. Vänkääminen sinänsä on ihan hauskaa ajanvietettä ja parempi vaihtoehto kuin esimerkiksi television katselu. (Mies, 55-64)

Verkkokeskusteluihin liittyy usein tunteiden purkaminen tai keskustelujen myötä syntyneiden ajatusten ilmaiseminen (Papacharissi 2004, 270). Keskusteluihin kirjoitettuja näkemyksiä ei tällöin puntaroida kovin pitkään eikä kyse aina ole tarkkaan harkitusta, rationaalisesta mielipiteenilmaisusta. Moni Suomi24-käyttäjä kokee, ettei nettikeskustelu ole niin vakavaa vaan ennemminkin hupia ja hauskuutta:

Katson, että kirjoittelu pitää virkeänä ja ylläpitää sujuvaa ilmaisutaitoa. Omasta mielestäni hauskojen kommenttien tuottaminen huvittaa joskus itseänikin. (Mies 55-64)

Muiden käyttäjien huumorintajua osattiin arvostaa, ja eräs vastaajista tunnusti olevansa itsekin tällainen humoristi:

Minusta on hauskaa kirjoittaa humoristisesti erityisesti julkkisjuorujen kohteista. Nimittelyä ja haukkumista en harrasta, vaan pyrin luomaan huvittavia kuvaelmia ja ideoita julkkisten elämästä sen perusteella, mitä he itse mediassa esittävät. (Nainen, 45-54)

Vastausten perusteella Suomi24:n keskustelukulttuuria luonnehtii nokkelien ja viihdyttävien viestiketjujen syntyminen. Nämä keskustelut kääntyvät helposti myös palstan omaksi sisäpiirivitsailuksi, joka aukeaa vain keskusteluja aktiivisesti seuraaville "palstavakkareille". 
Toisentyyppisten keskustelijoiden vastauksissa korostettiin tiedon jakamista ja oikean tiedon merkitystä. Näissä vastauksissa viitattiin faktojen ja asiantuntemuksen tärkeyteen ja keskustelujen seuraamisen motiivina oli tiedon etsiminen. Nämä vastaajat kiittelivät foorumia erityisesti siitä, että keskusteluista löytyy vastaus kysymykseen kuin kysymykseen. Vastaajat kehuvatkin kanssakeskustelijoiden asiantuntemusta, paikalla on aina joku, joka tietää ja jaksaa paneutua kysyjän esittämään ongelmaan. Jotkut ovat ottaneet asiakseen myös puuttua keskusteluihin virheellisten tietojen oikaisun merkeissä, kuten seuraavat sitaatit osoittavat:

Katson tekeväni nettikeskustelijana asiallista tiedon jakamista luterilaisesta kirkosta sekä herätysliikkeistä, joista liikkuu kaikenlaista disinformaatiota. Jonkun pitää tätäkin tehdä asialliselta pohjalta. (Nainen, 55-64)

[Jos foorumia ei olisi] ei [puuttuisi] mitään, koska olisi vain yksi paikka vähemmän, jossa joutuisi korjaamaan tahallista disinformaatiota ja ennakkoluulojen levitystä. (Mies, 45-54)

Keskusteluihin puuttujat löytyvät avovastausten perusteella foorumilta myös vastustamassa eri tahoihin kohdistuvaa vihakirjoittelua tai taistelemassa rasismia vastaan. He pyrkivät aktiivisesti vaikuttamaan keskustelukulttuuriin ja kamppailevat keskustelutilan hallinnasta häiriköiden kanssa. Näiden keskustelijoiden Suomi24-kokemusta määrittävät erityisesti törmäykset toisin ajattelevien ja erilaisen arvomaailman tai maailmankuvan omaavien kanssa. Törmäyksistä aiheutuu käyttäjille negatiivista tunnekuormaa ja turhautumista.

Verkkokeskusteluihin on Suomessa perinteisesti liitetty negatiivista leimaa (Östman 2013, 76-77). Verkkokeskusteluista puhuminen roskana tai käyttäjien Suomi24-foorumista viljelemä nimitys "Suoli24" kytkeytyvät tähän ilmiöön, vaikka Suoli24-puhe on myös foorumin käyttäjiä yhdistävää sisäpiirihuumoria.

Avovastauksissa myös kehuttiin kanssakeskustelijoita ja kiitettiin hyvää vuorovaikutusta heidän kanssaan. Lähes puolet vastaajista koki kuuluvansa foorumilla hänelle tärkeään ryhmään. Vertaistukeakin keskusteluista saatiin, sillä neljä viidestä kirjoittajasta koki auttavansa muita ja yli puolet heistä koki saaneensa tukea itse.

Nautin kirjoittamisesta ja saan tyydytystä, kun juttuni saa kommentteja muilta lukijoilta. [...] Samanhenkisten ihmisten bongaaminen keskusteluista on palkitsevaa. Samoin erilaisten elämänkokemusten jakaminen. (Nainen, 45-54)

Hyviä keskusteluita välistä, yllättävän fiksuja, aitoja tai muuten kiinnostavia ihmisiä, ihmiset kertovat asioistaan joskus yllättävän syvällisesti ja rehellisesti. (Nainen, 30-44)

Suomi24:nkin kokoisella laajalla keskustelufoorumilla voi olla yhteisöllisyyttä ja läheisyyden tunnetta synnyttävä luonne. Keskusteluihin osallistuminen kantaa vaikutuksia kirjoittajien verkon ulkopuoliseen elämään. Verkon sisäisten ja ulkopuolisten ihmiskontaktien raja ei ole kiinteä, vaan sosiaaliset suhteet kantavat toisinaan verkon 
yli ja liikkuvat näiden kahden tilan, onlinen ja offlinen välillä (Johansson 2011, Hine 2015). Suomi24-kyselyn perusteella verkkokeskusteluilla on joillekin käyttäjille voimauttava, jopa elämää muuttava merkitys, joka syntyy ihmiskontakteista ja vuorovaikutuksesta. Tämä ilmenee esimerkiksi seuraavista käyttäjien vastauksista kysymykseen, mitä elämästä puuttuisi, jos Suomi24-foorumia ei olisi:

Keskustelufoorumi. Ikäänkuin olisi yliopisto kotona. Ei tarvitse olla yksin ajatuksinensa vaan voi testata niitä keskustelussa muiden kanssa. Tämä on aivan uusi tilanne ihmiskunnalle. Kukaan ei ole yksin maaseudulla eristettynä tutkijoiden, ajattelijoiden, taiteilijoiden tms. seurasta. (Mies, 65-)

[U]udet ystävät, rohkeus, se, mitä olen nyt tajunnut elämästäni (ja tullut onnellisemmaksi). (Nainen, 30-44)

Foorumi on ollut käyttäjilleen siten myös paikka, jossa kohdata toisia ihmisiä. Syntyneiden ystävyyssuhteiden lisäksi joissakin avovastauksissa mainittiin Suomi24 Treffit -osio ja sen mahdollistamat vaikutukset käyttäjien elämään. Ihmisten kanssa vuorovaikuttamisen ja toisten ihmisten kohtaamisen myönteiset kuvaukset aineistossa esittävät ehkä parhaiten verkkokeskustelujen sosiaalista elämää rikastuttavan puolen.

Avovastauksissa korostui keskustelujen omakohtaisuus käyttäjille. Foorumilla keskustelevat osallistuvat keskusteluihin omista henkilökohtaisista lähtökohdistaan ja elämänkokemuksestaan käsin, viestien tältä pohjalta niin yhteiskunnallisista kuin intiimeistäkin asioista (ks. myös Vainikka, tulossa). Vaikka verkon mahdollistama sosiaalisuus voi tarjota vahvan tunteen toisten ihmisten kanssa viestimisestä ja yhteydenpidosta, anonyymeissä keskustelutiloissa kontakti on toisinaan huteralla pohjalla ja helposti kadotettavissa, kuten seuraava kertomus Suomi24-foorumilla käydystä keskustelusta osoittaa:

Kun taas itse kävin erittäin mukavaa keskustelua erään toisen henkilön kanssa, johon muutkin osallistuivat, mutta [toinen käyttäjä] oli saanut ilmeisesti poistettua koko ketjun ilmoittamalla, että meidän muiden keskustelut olisivat väärällä palstalla. Niitä ei oltu siirretty kyllä muuallekaan, vaan poistettu kokonaan, tuolloin menetin itse ainakin erään toisen henkilön kanssa käydyn keskustelun ja asiallisen ajatusten vaihdon. Ja ihan turhaan, harmittaa menetetty kirjoituskaveri, kuten muutama muukin kirjoittaja. Kumpikaan meistä ei ollut rekisteröityneitä, joten sinne menivät keskustelumme. (Nainen, 45-54)

\section{Keskustelutilan ongelmina asiattomuudet ja trollaaminen}

Yhteisöllisyyden ja tiedon jakamisen vastapuoleksi nousee joidenkin keskusteluviestien synnyttämä ahdistus sekä käyttäjien vahvasti kokema keskusteluiden asiattomuus. Asiattomasta keskustelusta syntyy myös epäluottamusta toisia käyttäjiä kohtaan. 
Avovastausten perusteella keskustelun asiattomuus on varsin näkyvä ilmiö, trollauksesta ja häiriköinnistä kirjoitettiin 161 vastauksessa. Lisäksi erikseen luokiteltu vihapuhe, rasismi ja väkivalta mainittiin 54 vastauksessa. Peräti 80 prosenttia vastaajista oli kokenut muut käyttäjät häiritseviksi Suomi24-keskusteluissa. Muutama mainitsee keskusteluista seuranneen itselleen yksityisyyden menettämisen, kuten tietojen levittelyn keskusteluissa, jokunen oli kokenut henkilökohtaista vainoa ja tappouhkauksia.

Epämiellyttäväksi koetun keskustelukulttuurin syypäiksi nähtiin toiset keskustelijat, joita kuvattiin lukuisissa vastauksissa vähemmän imartelevasti. Samalla vastaaja tuli asemoineeksi itsensä tämän joukon ulkopuolelle. Muut keskustelijat esitettiin 'toisina', epämääräisenä joukkona, johon vastaaja ei itse katsonut kuuluvansa (ks. myös Massanari 2015, 60). Suomi24-keskusteluiden muodostama kontaktivyöhyke tuo nämä toiset hyvin lähelle, verkon välityksellä kodin intiimiin yksityisen piiriin. Lukuisissa avovastauksissa viitattiin toisten keskustelijoiden oletettuun tyhmyyteen ja huonotapaisuuteen, heidän tuottamaansa vihapuheeseen, törkeyksiin ja yleiseen keskustelun häirintään:

Halveksin syvästi kirjoittajia, jotka eivät pysty argumentoimaan asiaa, vaan menevät vastapuolen (tai jonkun muun, esim. poliitikon) henkilöön syytämällä hänelle/hänestä pahinta laatua olevia törkeyksiä tai solvaamalla häntä toisille kirjoittajille täysin ala-arvoisin ilmauksin. Tällaiset kirjoittajat ovat ymmärtäneet sananvapauden täysin väärin. (Nainen, 65-)

Verkkokeskustelut karkaavat joskus hyvinkin kauas alkuperäisestä aiheesta ja toisinaan päädytään väittelemään keskustelun ja argumentoinnin periaatteista. Keskustelijat voivat puuttua kanssakeskustelijoiden lähdevalintoihin, argumentteihin tai kirjoitustyyliin (ks. Papacharissi 2004, 277). Kielioppivirheet, argumentoinnin heikkous ja keskustelijoiden tiedon puute ärsyttävät vastausten perusteella Suomi24:n käyttäjiä. Käyttäjät kaipasivat keskusteluihin sivistynyttä viestintää, oikeakielistä kirjoitusasua ja toiset huomioon ottavaa asennetta. Henkilökohtaisuuksiin meneminen ja tahallinen ilkeys olivat monen vastaajan mielestä foorumikeskusteluiden ikävimpiä piirteitä:

Monissa keskusteluissa ärsytetään, haukutaan ja loukataan tahallaan muita ihmisiä. Esim. naisviha, ulkomaalaisvastaisuus, työttömien syyllistäminen surettavat. Myös joihinkin suicidaalisiin viesteihin vastataan julmasti, että tapa itsesi. Ilmapiiri on ilkeä ja pahantahtoinen. (Nainen, 45-54)

Ihmisten kapean ajattelun heille aiheuttama kapea-alaisuus elämään ja asenteisiin, typerät kommentit joidenkin ehkäpä aitoon hätään ja avunpyyntöön. (Mies, 45-54)

Osa käyttäjistä pyrki löytämään selityksiä törkypostaajien käytökselle. Vihapuheen ja muiden keskustelijoiden solvaamisen taustalla nähtiin olevan paitsi ihmisten ilkeyttä, myös pahaa oloa tai mielenterveysongelmia. Lisäksi uskottiin, että pahimmat kommentit syntyvät humalatilan siivittämänä. Jotkut vastaajista arvelivat, että häiriköinnin takana ovat lapset ja nuoret. 
Keskusteluiden herättämiä negatiivisia tuntemuksia kysyttäessä vastaajat mainitsivat muun muassa turhautumisen keskustelualueita vallanneeseen asiattomaan kommentointiin, keskustelu oli ikään kuin mennyt pilalle ja he itse käyttäjinä olivat voimattomia tilanteen edessä. Toki nettikeskustelujen kielenkäyttö ja ilmaisutavat ovat kirjavia ja käyttäjät ovat voimakkaaseen nettikeskusteluun tottuneetkin. Käyttäjät kuitenkin kertoivat tunteneensa muun muassa pahoinvointia, ärtymystä, kiukkua, inhoa, mielipahaa, surua, turhautumista, ahdistusta, hämmennystä, myötähäpeää ja epätoivoa. Eräs vastaaja kuvaili palstan lukemista päivittäiseksi masokismituokioksi, toinen rinnasti kokemuksen auto-onnettomuuden näkemiseen: ei tekisi mieli katsoa, mutta uteliaisuus voittaa.

Suomi24:n palstoilla keskusteluja tahallaan häiriköivät trollit tuntuvat siis osin onnistuneen tehtävässään: he ovat saaneet joukon ihmisiä pois tolaltaan (ks. Phillips $2015,2)$. Trollit haastavat vakavissaan keskustelevat "internetissä mitään ei pidä ottaa vakavasti" -asenteellaan, tarkoituksenaan herättää voimakas reaktio, esimerkiksi vihaa tai kyyneleitä (Haara ym. 2017, 107). Samalla he ottavat keskustelutilan hallintaansa viemällä huomion pois varsinaisesta aiheesta tai estämällä keskustelun kokonaan. Eräs kyselyyn vastanneista listasi keskusteluissa havaitsemaansa häiriköinnin keinovalikoimaa seuraavasti:

Yleensä palstalla on joku häirikkö, joka tekee kaikkensa estääkseen asiallisen keskusteIun aiheesta. Häirikkö eli trolli häiritsee keskustelua, tekee asiattomia avauksia, sabotoi varastamalla muiden nimimerkkejä, ilmoittaa ylläpidolle asialliset keskustelut, jotta hänen omat viestinsä ovat ykkösinä, pyrkii ottamaan palstan omaan käyttöönsä, vaikuttamaan joskus selkeällä vihapuheella ja sen ankaralla toistamisella niihin, joilla ei ole omaa järkeä. Olen nähnyt tapauksia, että pari kolme trollia on yksissä tuumin ottanut koko palstan haltuunsa siten, että asialliset keskustelijat häipyvät. (Nainen, 45-54)

Häiriköinti vaihtelee jonkin verran foorumin eri keskustelualueiden välillä, mikä voi johtua erilaisesta käyttäjäkunnasta, kirjautumiskäytännöistä ja alueelle muodostuneesta omanlaisesta keskustelukulttuurista. Muut keskustelijat saattavat pyrkiä vaimentamaan häirikön olemalla huomioimatta tämän kommentteja lainkaan tai tekemällä hänet naurunalaiseksi. Jotkin keskustelunaiheet vetävät häiriköitä varmemmin puoleensa kuin toiset, mutta toisinaan keskustelu voi leimahtaa aggressiiviseksi pelkästä aloitusviestistä, jolloin esimerkiksi keskustelijoiden mielestä "tyhmiä" kyselevä saa tylyjä tai aggressiivisia vastauksia, tai hänet leimataan trolliksi, vaikka keskusteluaihe itsessään olisi asiallinen. Trolliksi kutsuminen voi olla käyttäjien taholta myös sen määrittämistä, kuka keskusteluissa saa puhua tai ketä tulisi kuunnella, kuka kuuluu keskustelupalstan sisäpiiriin, kuka on ulkopuolinen. (Pöyhtäri ym. 2013, 81-82; Fuller ym. 2013, 1.)

Raja keskustelua häiriköivien ja asiallisten keskustelijoiden välillä ei ole selvä. Ketjuihin trollausmotiivilla kirjoittavien lisäksi muutkin keskustelijat voivat lämmetä sanasotiin. Kuka tahansa saattaa tulla keskustelupalstalla häirityksi, mutta samaan tapaan myös niin sanottu asiallinen keskustelija voi provosoitua mukaan aggressii- 
viseen keskusteluun. Papacharissi (2004, 277) havaitsi uutisryhmiä (Usenet newsgroups) koskevassa tutkimuksessaan, miten keskustelun tuoksinassa spontaanisti syntynyt asiaton keskustelu lientyi nopeasti keskustelijoiden puuttuessa asiattomuuksiin ja miten epäasiallisesti kirjoittaneet näissä tilanteissa usein itse pahoittelivat kiihtymistään. Sen sijaan tiukasti keskustelijoiden asenteisiin kiinnittyvän asiattoman ja epädemokraattisen kommentoinnin, esimerkiksi ihmisryhmiin kohdistuvien loukkausten ollessa kyseessä, keskustelu ei rauhoittunut eikä asiattomuuksia pahoiteltu jälkikäteen.

Kyvyttömyyttä tai haluttomuutta vaikuttaa Suomi24-keskustelukulttuuriin heijastelevat kyyniset tai mustaksi huumoriksi heitetyt lausunnot keskustelun laadusta:

\section{Kaikki puhuu pelkkää paskaa. Sitä varten sivusto on. (Mies, alle 30)}

Moni käyttäjistä myös mainitsi, ettei helposti häiriinny törkyviesteistä. Häiriköinti nähtiin osaksi verkkokeskusteluja, muuallakin kuin Suomi24:ssä, ja sen joukossa tulee vain osata luovia. "Herkkiksiä" kehotettiin kovettamaan itsensä:

\section{[...] Eihän kukaan vähemmän järkevä, eli siis tavallista nöyrää ihmistä vähän fiksumpi,} kommentoi omalla nimellä kaikkea sitä paskaa mitä tykkään lukea. Ai että miten kamalaa olisi, jos pitäisi olettaa että muut seisoo sanojensa takana ja itsekin pitäisi jatkuvasti kontrolloida itseään. Ei kiitos. Herkkikset vois kasvattaa vähän selkäkarvoja. (Ei tietoa sukupuolesta, 30-44)

Osalle Suomi24 edustaa keskustelutilaa, jossa voi purkaa mieltään ja ikään kuin sallitusti hyökätä muita ihmisiä vastaan. Myös häiriköiksi tunnustautuvia vastaajien joukossa oli, sillä foorumi mainittiin useamman kerran helpoksi ja nopeaksi trollauspaikaksi. Tai kuten seuraavat sitaatit foorumia luonnehtivat:

\section{Kätevä paikka trollailla pösilöitä. (Ei tietoa sukupuolesta eikä iästä.)}

Paikka kiusata ja debunkata ${ }^{5}$ kihkoilijoita. (Mies, 30-44)

Foorumia ja sen käyttäjiä häiriköidessään trolli pitää kohteitaan vähemmässä arvossa kuin nämä itse. Trolli muuntaa keskustelun peliksi ja manipuloi käyttäjiä tunnereaktioita synnyttämällä peliin mukaan. (Fuller ym. 2013, 1-2.) Trollaamisen helppoutta tai kätevyyttä ei kyselyvastauksissa sen kummemmin selitetty. Anonyymiys lienee yksi olennainen tekijä, mutta sitaatit yllä antavat viitteitä myös tulkintaan, että Suomi24-keskustelupalstoilla saadaan helposti muita keskustelijoita provosoitumaan.

Joillekin vastaajista keskustelujen laaduttomuus oli liikaa. He kuvailivatkin jo vähentäneensä keskustelufoorumin seuraamista tai vaihtaneensa tasokkaammille foorumeille. Näiden luopujien joukossa oli myös foorumin teknisiin ominaisuuksiin ja moderointiin tai niissä tapahtuneisiin muutoksiin pettyneitä. 


\section{Keskustelujen hallitsemattomuus ja moderoinnin kaipuu}

Keskustelufoorumeilla moderointi torjuu verkkotilan uhkia ja laittomuuksiin menevää tai epäkorrektia keskustelua (Lehtisalo 2011, 114). Suomi24-keskusteluja moderoidaan palstoja seuraamalla ja kävijöiden poistopyyntöjen perusteella, nyttemmin myös tekoälyn avulla (Aller 2017). Poistetuista viesteistä jää foorumille näkyviin tieto viestin poistamisesta. Osa keskustelualueista pysyy helposti siisteinä, eivätkä ne siten vaadi toimenpiteitä, toisissa keskustelu taas helposti villiintyy. (Lagus ym. 2016, 9-10.) Asiattomiksi keskustelualueiksi avovastauksissa nousevat esiin muun muassa muutamaa paikkakuntaa koskevat keskustelut, uskontoa ja ateismia käsittelevät keskustelut, ihmissuhde- ja sinkkupalstat sekä autoiluun ja matkailuun liittyvät keskustelut.

Keskustelufoorumeilla käydään jatkuvaa neuvottelua siitä, kuka käyttää valtaa ja määrittää keskustelun säännöt (Lehtisalo 2011, 114). Yleensä perimmäinen määrittelyvalta on sivuston ylläpitäjällä ja keskustelualueiden moderaattoreilla. Suomi24keskusteluja valvomassa ovat aiemmin olleet mukana myös vapaaehtoiset moderaattorit, luotsit ${ }^{6}$.

Useat vastaajat kokivat keskustelujen moderoinnin kaipaavan kehittämistä. Moderointia arvosteltiin tehottomaksi: häiriköintiä sallittiin vastaajien mukaan liian vapaasti, eikä asiattomuuksiin puututa riittävästi (ks. myös Massanari 2015, 79).

Jotkut vakituiset "keskustelijat" käyttävät satoja tai tuhansia nimimerkkejä tarkoituksenaan vain räyhätä, loukata tiettyjä (yleensä rekisteröityneitä) nimimerkkejä ja häiritä asiallista keskustelua, eikä ylläpito näköjään edes halua voida näille ilmanpilaajille mitään. (Mies, 55-64)

Jotkut käyttäjät kantoivat huolta muiden keskustelijoiden kyvystä ottaa vastaan asiatonta kommentointia, erityisesti näissä vastauksissa mainittiin nuoret tai muuten avun tai tuen tarpeessa olevat. Moderoinnin tehtävänä oli tällöin myös käyttäjien suojelu.

Toisten ihmisten tahallinen loukkaaminen tilanteissa, joissa joku ihminen on selvästi hakemassa tukea vaikeassa tilanteessa, on inhottavaa. Sellainen kuitenkin valitettavasti kuuluu kaikkien suosittujen verkkofoorumeiden luonteeseen ja ainoa keino sen taltuttamiseksi ovat palstaeditorit. [...] Nuorten palstoilla ja ulkonäköä, dieettejä ym. käsittelevillä palstoilla voisi olla nopeampi moderaatio, koska nuorilla on usein huono itsetunto. Itse olen ollut niin kauan verkossa, että osaan jo suhteuttaa asioita. (Nainen, 30-44)

Joissakin vastauksissa viitattiin moderaattorien asiantuntemattomuuteen, nämä käyttäjät, kuten alla olevan sitaatin kirjoittaja, pitivät tärkeänä, että moderaattorit tietävät myös keskustelun aiheista ja puuttuvat väärän tiedon levittämiseen: 
Moderoijan pitäisi pystyä tietämään alueensa aiheista ja katsoa mitä siellä julkaistaan, palstalle jäävä virheellinen tieto jonka käyttäjä saa, voi suututtaa käyttäjän ja käyttäjä voi haukkua palstaa tuttavilleen ja muillekin - aiheesta. Ei se riitä, että poistetaan kirosanat, pitäisi poistaa myös turhanpäiväiset viestit ja tarkistaa tietojen oikeellisuus. (Mies, 45-54)

Jos kohta keskustelujen valvonnan tehottomuus oli kritiikin kohteena, joidenkin vastaajien mielestä moderaattorit olivat liiankin aktiivisia ja tehokkaita. Moderoinnin tulkittiin olevan puolueellista tai vallan väärinkäyttöä:

Palstalla osa moderaattoreista on vallankäyttäjiä, jotka nauttivat siitä, että saavat poistaa inhoamiensa henkilöiden mielipiteitä, vaikka ne olisivat asiallisia. (Mies, 55-64)

Suomi24-foorumin aiempi käytäntö osallistaa käyttäjiä "luotseiksi" tuotti heille kaksoisroolin keskusteluihin osallistujana ja niiden valvojana, moderointivallan käyttäjinä. Tämä on saattanut rakentaa jännitteitä luotsien ja muiden käyttäjien välille. Yllä siteerattu vastaaja myös kehui samassa vastauksessa hakkeroineensa esiin yhden, vastaajan mielestä väärällä tapaa valtaa käyttäneen luotsin todellisen henkilöllisyyden ja savustaneensa hänet ulos foorumilta. Miten savustaminen käytännössä tapahtui, sitä vastaus ei paljasta. Tämä on kuitenkin aineistossa yleisemmästä keskustelujen häiriköintipuheesta poikkeava esimerkki siitä, miten käyttäjä on ottanut keskustelutilassa vallan käsiinsä, kyseenalaisin keinoin.

Keskustelijat yrittävät itsekin vaikuttaa keskustelun asiallisena pysymiseen. 43 prosenttia kyselyn vastaajista oli pyytänyt moderaattoria poistamaan häiritsevän viestin. Avovastauksista on pääteltävissä, että käyttäjillä on kuitenkin jonkinasteinen sietokyky asiattomuuksia kohdatessaan ja moderaattoreille ilmoitetaan vain pahimmat viestit:

Vihapuheet ovat oma lukunsa, ja jätän ne omaan arvoonsa. Pahimmissa tapauksissa laitan ylläpidolle viestiä roskan poistamiseksi. (Mies, 65-)

Asiattomuuksien ja häiriköinnin nähtiin näissä vastauksissa pilaavan koko keskustelun ja osa vastaajista mainitsi tästä syystä siirtyneensä Suomi24-keskusteluista toisille foorumeille tai ainakin valikoivansa seuraamiaan keskustelualueita:

Olen visusti välttänyt eksymästä maahanmuuttoa, poliittista tilannetta tai muuta tunteita herättävää keskustelua sisältäville sivuille negatiivisuuden ja epäasiallisen kielenkäytön vuoksi. En halua tahallisesti hakeutua kurjaa oloa tuoviin keskusteluihin. (Nainen, 30-44)

Näin käyttäjät voivat omilla toimillaan suojautua kielteiseltä tunnekuormalta. Vastaajista osa arvioi, että moderointi keskustelufoorumilla on ajan mittaan muuttunut huonommaksi:

Taso on laskenut kuin lehmän häntä. Älyköt on korvautuneet hulluilla. Luotsijärjestelmä on epäonnistunut ja fiksut seriffit on potkittu ulos ja tilalle on tullut lauma hörhöjä. (Ei tietoa sukupuolesta, 45-54) 
Eräs käyttäjä kuvaili, miten toinen keskustelija oli vaikuttanut hänen kommentointiinsa ja saanut häntä siistimään omaa kirjoitteluaan:

Kun seurasin Johanna Tukiaisesta "kulttuurikeskustelua" niin [toinen keskustelija jonka nimimerkki poistettu tästä - AH] esiintyi sinnikkäästi laintuntijan ominaisuudessa ja esimerkkikansalaisen perikuvana ja puolusteli lain puitteissa [Tukiaista, jolloin tuo toinen keskustelija] oli sopiva moraalinjuurruttaja, etten itse alkanut roimimaan sitä tanssitirehtööriä kuin vierasta sikaa. (Muu, ei tietoa iästä)

Keskustelijat voivatkin vaihdella rooliaan asiallisen ja asiattoman keskustelijan välillä. Noin neljäkymmentä prosenttia vastaajista oli kohdannut omien kommenttiensa moderointia. Samansuuruinen joukko vastaajista myönsi myös ärsyttäneensä tahallaan toisia keskustelijoita, kahdeksan prosenttia vastaajista oli tehnyt tätä usein. Keskustelujen trollaushenkinen häiriköinti voi olla myös keskustelukulttuuriin liittyvää huvittelua ja ajanvietettä (Nikunen \& Pantti 2017). Se, mitä tällaisesta toiminnasta seuraa, on käyttäjien tiedossa ja ainakin jossain määrin hyväksyttyä:

Banneja on tullut kaksi, mutta ne ovat aiheesta ja ei tulisi mieleenkään purnata niistä.

Joskus on poistettu viestejä, jotka eivät sovi eräille tahoille, mutta se on ihan normaalia nykymaailmassa. (Mies, ei tietoa iästä)

Nekin käyttäjät, jotka eivät itse häiriköintiin sorru, saattavat yhtä aikaa paheksua trollausta ja nauttia siitä, miten keskustelujen tunneintensiteetti kasvaa keskustelijoiden provosoitumisen myötä (Paasonen 2014, 30).

Noin puolet käyttäjistä vastasi kyselyssä, että keskusteluviestien poistaminen ei ollut koskaan häirinnyt heitä. Lääkkeeksi häiriköintiin tarjottiin avovastauksissa nimimerkin rekisteröintipakkoa. Tätä vastaajat perustelivat kokemuksillaan, joissa rekisteröintipakko oli auttanut tilannetta toisella asiattomaksi villiintyneellä foorumilla. Myös Pöyhtärin ja kumppaneiden $(2013,210)$ haastattelemat eri keskustelufoorumien moderaattorit kokivat rekisteröitymisen hillinneen häiriköintiä: kaikki häiriköintitarkoituksessa foorumille tulevat eivät viitsi rekisteröityä. Myös rekisteröitymättömistä käyttäjistä foorumien ylläpidolla on paljon sekä tietoa että kokemuksen tuomaa tuntumaa. Voikin sanoa, että moderaattorit tuntevat keskustelufoorumin käyttäjät paremmin kuin nämä osaavat arvatakaan.

\section{Anonyymi kirjoittelu mahdollistaa sekä sananvapauden että häiriköinnin}

Häiriköintiin voidaan suhtautua joko sen merkitystä vähätellen tai sitten sen nähdään vaikuttavan omaan tai muiden toimintaan (Pöyhtäri ym. 2013, 131). Suomi24-käyttäjäkyselyn avovastauksissa esiintyi kahta puhetapaa, joista toinen käsitteli anonyymejä kommentteja ja toinen taas asiattomuuksia kirjoittavia käyttäjiä (vrt. Reader 2012, 
500-502). Keskustelua kuvattiin muun muassa roskapostiksi, paskanpuhumiseksi, sosiaalipornoksi, oksennukseksi ja saastaksi. Keskustelijoita määriteltiin vastauksissa esimerkiksi sivistymättömiksi, asennevammaisiksi, katkeriksi, häiriintyneiksi ja raivohulluiksi provokaattoreiksi.

Anonyymi kirjoittamismahdollisuus voidaan nähdä myös myönteisenä ilmiönä. Anonyymit keskustelut säilyttävät vallan käyttäjien omissa käsissä, kun valtavirrasta poikkeavat näkemykset pääsevät esiin ilman pelkoa niitä esittävien henkilöiden leimautumisesta. Keskustelufoorumien käyttäjät voivat myös olla huolestuneita keskusteluja ääneti seuraavista, osallistumattomista käyttäjistä, keitä he ovat ja miten he käyttävät foorumilla esitettyjä näkemyksiä. Anonymiteetti suojelee tällöin kirjoittajien yksityisyyttä. Anonyymi kirjoittelu ei myöskään ole irrallaan yhteiskunnan todellisuudesta. Vaikka käyttäjät kokisivatkin joidenkin mielipiteiden, esimerkiksi vihakirjoittelun, lukemisen raskaaksi, nämä epämiellyttävät mielipiteet paljastavat tiettyjen asenteiden ja ajatusten olemassaolon, eikä niitä poisteta yhteiskunnasta kieltämällä niiden esittäminen. (Reader 2012, 502-504.) Vastauksissa Suomi24 nähtiin yhdeksi niistä harvoista verkossa sijaitsevista keskustelutiloista, joissa pystyy kirjoittamaan täysin vapaasti ja anonyymisti arkaluontoisista aiheista tai epäkorrekteiksi leimatuista mielipiteistä:

Suomenkielinen, anonyymi kansan ääni, johon kuka vain voi osallistua. Anonyyminä voi käsitellä myös arkoja tai henkilökohtaisia aiheita, kuten painoa ja laihduttamista tai kotiin ja perheeseen kuuluvia asioita. (Nainen, 45-54)

[...] Suomi24-sivulla käyn siitä syystä, että sitä ei ennakkomoderoida. Se on pieni valopilkku vihapuhehysterian ja kulttuurimarxistien saastuttamassa (rasisti, fobia sitä ja tätä blää, blää, blää) kotimaisessa online-keskustelussa. (Mies, 45-54)

Nopparin $(2013,67)$ tekemässä journalismiin ja sosiaalisen median keskusteluihin liittyvässä avoimessa internetkyselyssä joka neljäs vastaaja kertoi mieluiten esiintyvänsä verkon keskusteluissa anonyyminä. Myös Suomi24-kyselyyn vastanneet käyttäjät suosivat yhdellä tai useammalla nimimerkillä kirjoittamista. Joukossa oli kuitenkin joitakin kymmeniä vastaajia, jotka olivat ainakin joskus kirjoittaneet keskusteluihin omalla nimellään. Avovastauksissa jotkut Suomi24-foorumin käyttäjistä näkivät anonyymin kirjoittelumahdollisuuden tärkeäksi edellytykseksi avoimelle ja vapaalle keskustelukulttuurille. Verkkokeskustelua koskevissa tutkimuksissa on myös havaittu, että anonyymeissa keskusteluissa osallistuminen on laajempaa: esimerkiksi vähemmistöryhmiin kuuluvat pääsevät ääneen todennäköisemmin ja näkemysten kirjo on moninaisempi kuin keskusteluissa, joissa kirjoittaja joutuu tunnistautumaan (Reader 2012, 498; McCluskey \& Hmielowski 2011, 324).

Erityisesti arkaluontoisissa aihepiireissä nimettömyyden tarjoama suoja on tärkeää, mutta anonyymiys on käyttäjille myös arvo itsessään. Osa tätä vapaan sanan keskustelukulttuuria arvostavista kritisoi Suomi24:n moderaattoreita tiukkapipoisuudesta ja puolueellisuudesta viestien poistamisessa. Pöyhtärin ja kumppaneiden 
haastattelemat moderaattorit kuitenkin muistuttavat, että usein juuri anonyymit keskustelijat hyökkäävyydellään vaientavat muita keskustelijoita ja näin estävät näiden sananvapauden toteutumista. Toisaalta moderaattorit tunnistivat myös, että on olemassa aiheita, joista on tarpeen pystyä keskustelemaan täysin anonyymisti, ilman mahdollisesti tunnistettavaa nimimerkkiä. Eikä anonyymin kirjoitusmahdollisuuden poistaminen poista myöskään kaikkia häiriköitä, sillä osalle verkkokeskustelijoista on haastateltujen moderaattorien mukaan tyypillistä nimenomaan huomion hakeminen ja oman nettimaineen kerääminen. Tätä toteutetaan tunnistettavalla nimimerkillä tai avoimesti omalla nimellä. (Pöyhtäri ym. 2013, 210-211.)

\section{Lopuksi: Suomi24 moniulotteisena kontaktivyöhykkeenä}

Käyttäjäkyselyn avovastauksissa Suomi24 rakentui yhteiseksi alueeksi, jonka kirjoittamattomiin toimintasääntöihin etenkin aktiiviset keskustelijat ja kauan foorumia käyttäneet haluavat vaikuttaa. Käyttäjillä oli kuitenkin erilaisia näkemyksiä foorumin käyttötavoista ja -tarkoituksista. Vastaukset tekivätkin näkyväksi sen kamppailun, jota foorumitilan ja sillä käytävän keskustelun hallinnasta käydään. Vastauksissa yhtäältä vaadittiin sivistynyttä ja toisia kunnioittavaa keskustelua, toisaalta liputettiin täydellisen sananvapauden puolesta, ja osa vastaajista jopa näki myönteiseksi sen, että foorumi mahdollistaa paitsi anonyymin kirjoittamisen, myös trollaamisen ja muun keskustelun hämmentämisen.

Avovastaukset kertoivat keskustelualueilla syntyneistä kohtaamisista muiden keskustelijoiden kanssa. Osa kuvasi yhteisöllisyyden ja ystävyyden kokemuksia, mutta suurta osaa avovastausaineistosta määritti käyttäjä- ja keskustelukulttuurien törmäämisen kokemusten ja niiden herättämien negatiivisten tunnereaktioiden kuvailu. Tätä puhetta leimasi eronteko itsen ja muiden välillä, toisia keskustelijoita myös arvosteltiin kovin sanoin. Näin Suomi24-keskustelut näyttäytyvät kontaktivyöhykkeenä, kulttuurisena tilana, jossa käyttäjät kohtaavat inmisiä ja ajatuksia omien sosiaalisten piiriensä ulkopuolelta (Pratt 2008 [1992]).

Foorumin laajuus, pitkä historia ja suuret käyttäjämäärät tekevät siitä merkittävän alueen suomalaisen sosiaalisen median kartalla. Vaikka käyttäjien mielestä Suomi24:n keskustelualue olisikin usein "Suoli24" tai "likakuoppa" "täynnä roskaa", silti yksittäiset keskustelut ja keskustelujen mahdollistamat inmiskontaktit olivat heille hyvin merkityksellisiä. Vaikka anonyymien isojen foorumien käyttöön liittyy ala-arvoisen keskustelun stigmaa, eikä kovin moni julkisesti mainosta osallistuvansa niillä käytyyn keskusteluun, foorumien käyttöön liittyy kuitenkin myös mielihyvän, ilon ja hyödyn kokemuksia. Tämä edellyttää toisinaan keskustelukulttuuriin liittyvien ikävien ilmiöiden, kuten vihapuheen, häiriköinnin ja keskustelujen hallitsemattomuuden tunnun sietämistä. Suomi24-keskusteluiden käyttökokemusta määrittelee kyselyaineiston perusteella yhtä aikaa sekä keskusteluiden vuorovaikutuksellinen vetovoima että tarve ottaa keskusteluihin etäisyyttä häiriköinnin aiheuttaman tunnekuormituksen takia. 
Käyttäjille ei ole rakentunut vahvaa osallisuutta keskustelufoorumin käyttöön ja sen keskustelukulttuuriin siinä mielessä, että he kokisivat omaavansa juurikaan vaikutusvaltaa häiriköiden toimintaan tai kohtaamiinsa moderoinnin ongelmiin. Moderointi sai käyttäjiltä osakseen enimmäkseen moitteita: sitä arvioitiin tehottomaksi, asiattomuuksia sallivaksi ja jopa puolueelliseksi. Anonyymin keskustelumahdollisuuden nähtiin mahdollistavan asiattoman kirjoittelun ja keskustelualueilla häiriköinnin. Toisaalta vastaajissa oli myös niitä keskustelijoita, jotka kiittelivät Suomi24:n olevan niitä viimeisiä vapaan mielipiteen ilmaisun paikkoja, joissa asioita ei tarvitse esittää omilla kasvoilla tai rekisteröityyn nimimerkkiin kiinnittyen. Tätä mahdollisuutta arvostivat paitsi sananvapautta puolustavat keskustelijat, myös ne vastaajat, jotka tunnustivat tulevansa foorumille trollaamaan ja provosoimaan muita keskustelijoita. Trollaaminen myös kyseenalaistaa foorumin valtarakenteita, sivuston ohjeita sekä käyttäjien kesken syntyneitä kirjoittamattomia sääntöjä siitä, mikä keskusteluissa on sopivaa.

Toimintamahdollisuuksiksi häiriköintiä vastaan avovastauksissa nousivat esiin sietokyvyn kasvattaminen tai foorumilta poistuminen. Vain muutama mainitsi yrittäneensä vaikuttaa keskustelun kulkuun faktoja korjaamalla tai ilmiantamalla häiritsevät viestit. Toisaalta avokysymysten muoto ei myöskään ollut omiaan houkuttelemaan esiin käyttäjien omaa toimintaa koskevaa puhetta. Kiinnostava jatkotutkimuksen aihe olisikin selvittää, millaista osallisuutta käyttäjät kokevat foorumin keskustelukulttuurin muotoutumiseen. Tässä analyysissä tällaiseksi osallisuudeksi nousi esiin lähinnä kokemus yhteisön jäsenyydestä; kokemusten jakaminen, toisten auttaminen ja avunsaanti.

\section{Kiitokset}

Työryhmä Kari Saari, Juho Saari, Krista Lagus ja Minna Ruckenstein Citizen Mindscapes -tutkimuskonsortiosta suunnittelivat käyttäjäkyselyn. Sen toteutti ja dokumentoi Kari Saari. Artikkelikäsikirjoitukseen sain työtä eteenpäin vieviä kommentteja Juho Saarelta ja Minna Ruckensteinilta Citizen Mindscapes -konsortiosta, Eliisa Vainikalta ja Seija Ridelliltä Tampereen yliopiston Viestintätieteiden tiedekunnasta sekä Media \& viestintä -lehden anonyymeiltä vertaisarvioijilta. 


\section{Viitteet}

Citizen Mindscapes on Suomen Akatemian rahoittama tutkimushanke, joka tutkii Suomi24keskusteluaineiston avulla sosiaalisen median keskustelukulttuuria, kehittää tilastollisia ja kieliteknologisia menetelmiä sekä visuaalisia työkaluja. Hankkeessa selvitetään, minkälaisia vuorovaikutuksen lajeja Suomi24-aineistosta löytyy, miten kiihkeät keskustelut muuntuvat poliittisiksi liikkeiksi ja miten keskusteluista voitaisiin tunnistaa tunneaaltoja. Hankkeen blogi: http://blogs.helsinki.fi/citizenmindscapes/.

2 Merkittävä osa Suomi24-foorumin kävijöistä tulee keskusteluihin Google-hakujen kautta. Palvelun satunnaiset selaajat lukevat vain muutaman keskustelun, kun taas aktiiviset keskustelijat viettävät foorumilla aikaansa päivittäin. (Lagus ym. 2016, 9.)

3 Koodausrungossa oli kaikkiaan 24 aineistoluokkaa, jotka sisälsivät muun muassa käyttäjien näkemyksiä keskusteluaiheista, foorumin yhteisöllisistä piirteistä, vertaistuesta, keskusteluihin osallistumisen motivaatioista sekä Suomi24:n vertailua muihin medioihin niin sosiaalisen median kuin journalisminkin kentällä.

4 Suomi24-palvelu kuvaa itseään Suomen suurimmaksi verkkoyhteisöksi ja kaikille avoimeksi, maksuttomaksi kanavaksi keskusteluun ja mielipiteiden vaihtoon. Suomi24:n omistaa ja sitä ylläpitää Aller. Keskusteluiden lisäksi foorumilla on myös muita palveluita: Treffit, Alennuskoodit, Matkat, Posti ja Chat.

5 Debunkkauksella tarkoitetaan toisen keskustelijan väitteiden osoittamista epätosiksi.

6 Suomi24-keskustelujen luotsijärjestelmä on sittemmin poistunut käytöstä. Keskusteluja moderoidaan palkattujen moderaattoreiden sekä tekoälyn voimin. Konemoderointi otettiin käyttöön vuonna 2017, mutta sitä pilotoitiin jo vuoden 2016 puolella, myös käyttäjäkyselyn aikaan (Aller 2017). Tekoälyn "harjoittelujakso" saattaakin heijastua joissakin moderointia käsittelevissä avovastauksissa, esimerkiksi moderaattoreiden tekemisten kummasteluna.

\section{Kirjallisuus}

Aller (14.2.2017). Aller pilotoi tekoälyn käyttöä Suomi 24:n moderoinnissa. Saatavilla: https://www.aller.fi/ aller-pilotoi-tekoalyn-kayttoa-suomi24n-moderoinnissa/ (Luettu 12.2.2018).

Arpo, Robert (2005). Internetin keskustelukulttuurit. Tutkimus internet-keskusteluryhmien viesteissä rakentuvista puhetavoista, tulkinnoista ja tulkinnan kehyksistä kommunikaatioyhteiskunnassa. Väitöskirja. Joensuun yliopiston humanistisia julkaisuja no 39. Joensuu: Joensuun yliopistopaino.

Baym, Nancy K. (2010). Personal Connections in the Digital Age. Cambridge: Polity Press.

Freelon, Deen (2015). Discourse architecture, ideology, and democratic norms in online political discussion. New Media Q Society 17:5, 772-791. https://doi.org/10.1177/1461444813513259

Fuller, Glen; McCrea, Christian \& Wilson, Jason (2013). Troll theory? The Fibreculture Journal 22(2013) 1-14. Saatavilla: http://twentytwo.fibreculturejournal.org/ (Luettu 23.1.2018).

Graham, Todd \& Harju, Auli (2011). Reality TV as a trigger of everyday political talk in the net-based public sphere. European Journal of Communication 26:1, 18-32. https://doi.org/10.1177/0267323110394858

Graham, Todd; Jackson, Daniel \& Wright, Scott (2016). 'We need to get together and make ourselves heard': everyday online spaces as incubators of political action. Information, Communication Q Society 19:10, 1373-1389. https://doi.org/10.1080/1369118X.2015.1094113

Haara, Paula; Hiltunen, Ilmari \& Vainikka, Eliisa (2017). Trollaamisen kulttuurin logiikka. Media Q viestintä 40:1-2, 107-111.

Hall, Stuart (2003). Kulttuuri, paikka, identiteetti. Teoksessa: Lehtonen, Mikko \& Löytty, Olli (toim.) Erilaisuus. Tampere: Vastapaino. [Alkuteos: Hall, Stuart (1995). New cultures for the old. Teoksessa: Massey, Doreen \& Jess, Pat (toim.) (1995). A Place in the World. Milton Keynes: The Open University.] Suom. Juha Koivisto, 85-128.

Hine, Christine (2015). Ethnography for the Internet: Embedded, Embodied and Everyday. Lontoo: Bloomsbury Academic.

Hirschkind, Charles; de Abreu, Maria José A. \& Caduff, Carlo (2017). New media, new publics? An introduction to supplement 15. Current Anthropology Vol.15 Supplement 15, 3-12. https://doi.org/10.1086/688903

Jenkins, Henry (2006). Convergence Culture. Where Old and New Media Collide. New York: Polity Press. 
Johansson, Sofia (2011). Connection or disconnection? Two generations in Sweden discuss online sociality. Teoksessa: Feilitzen, Cecilia von \& Petrov, Peter (toim.) Use and Views of Media in Sweden Q Russia: A Contemporary Study in St. Petersburg Q Stockholm. Mediestudier vid Södertörns högskola; Journal number 2011:1, Huddinge: Södertörns högskola, 271-296.

Kangaspunta, Veera (2016). Talvivaara ja kommenteissa keskustelevat julkisot. Media Q viestintä 39:1, 24-54. https://doi.org/10.23983/mv.61438

Kozinets, Robert V. (2015). Netnography: Redefined. 2nd edition. Lontoo: Sage.

Lagus, Krista; Pantzar, Mika \& Ruckenstein, Minna (2015). Keskustelun tunneaallot - Suomi24-hanke. Tieteessä tapahtuu 6/2015, 39-41.

Lagus, Krista; Pantzar, Mika; Ruckenstein, Minna \& Ylisiurua, Marjoriikka (2016). SUOM/24 Muodonantoa aineistolle. Kuluttajatutkimuskeskus, Valtiotieteellisen tiedekunnan julkaisuja 2016:10. Helsinki: Helsingin yliopisto. Saatavilla: http://blogs.helsinki.fi/citizenmindscapes/ files/2016/05/257383_HY_VALT_suomi24_muodonantoa_aineistolle.pdf (Luettu 29.8.2017).

Lehtisalo, Anneli (2011). "Tänne kaikki nyt moi." Tyttöjenlehdet kohtaamisen ja vuorovaikutuksen tiloina. Tampere: Journalismin, viestinnän ja median tutkimuskeskus Comet.

Malinen, Sanna (2015). Understanding user participation in online communities: A systematic literature review of empirical studies. Computers in Human Behavior 46(2015), 228-238. https://doi.org/10.1016/j.chb.2015.01.004

Massanari, Adrienne L. (2015). Participatory Culture, Community, and Play. Learning from Reddit. New York: Peter Lang. https://doi.org/10.3726/978-1-4539-1501-1

Matikainen, Janne (2008). Sosiaalinen media - millaista sosiaalisuutta? Tiedotustutkimus 31:4, 24-41. https://doi.org/10.23983/mv.63013

McCluskey, Michael \& Hmielowski, Jay (2011). Opinion expression during social conflict: Comparing online reader comments and letters to the editor. Journalism 13:3, 303-319. https://doi.org/10.1177/1464884911421696

Mikal, Jude P.; Rice, Ronald E.; Kent, Robert G. \& Uchino, Bert N. (2014). Common voice: analysis of content convergence on a website characterized by group identification and social attraction. Computers in Human Behavior 35(2014), 506-515. https://doi.org/10.1016/j.chb.2014.02.036

Milner, Ryan M. (2013). Hacking the social: internet memes, identity antagonism, and the logic of lulz. The Fibreculture Journal 22(2013), 61-91. Saatavilla: http://twentytwo.fibreculturejournal.org/ fcj-156-hacking-the-social-internet-memes-identity-antagonism-and-the-logic-of-lulz/ (Luettu 23.1.2018).

Nikunen, Kaarina (2010). Rakastamisen vaikeudesta: Internet, maahanmuuttokeskustelu ja tunteet. Media Q viestintä 33:4, 7-26. https://doi.org/10.23983/mv.62919

Nikunen, Kaarina \& Pantti Mervi (2017). Affektiivinen julkisuus, moraaliset tunteet ja tahmaiset kuvat: Tapaus Ku Klux Klan. Teoksessa: Maasilta, Mari \& Nikunen, Kaarina (toim.) Pakolaisuus, tunteet ja media. Tampere: Vastapaino, 71-91.

Noppari, Elina (2013). Toimittajat kohtaavat (kriittisen) nettikansan. Teoksessa: Vainikka, Eliisa; Noppari, Elina; Heinonen, Ari \& Huhtamäki, Jukka. Twiiteryhmiä ja uutispäivittelyä - toimittajana sosiaalisessa mediassa. Tampereen yliopisto: Journalismin, viestinnän ja median tutkimuskeskus Comet, 66-97.

Paasonen, Susanna (2014). Juhannustanssien nopea roihu ja Facebook-keskustelun tunneintensiteetit. Media Q viestintä 37:4, 22-39. https://doi.org/10.23983/mv.62836

Papacharissi, Zizi (2004). Democracy online: civility, politeness, and the democratic potential of online political discussion groups. New Media Q Society 6:2, 259-283.

https://doi.org/10.1177/1461444804041444

Pariser, Eli (2011). The Filter Bubble: What the Internet Is Hiding from You. New York, NY: The Penguin Press.

Phillips, Whitney (2015). This Is Why We Can't Have Nice Things. Mapping the Relationship between Online Trolling and Mainstream Culture. Cambridge: MIT Press.

Pink, Sarah; Ruckenstein, Minna; Willim, Robert \& Duque, Melisa (2018). Broken data: Conceptualising data in an emerging world. Big Data Q Society 5:1, 1-13. https://doi.org/10.1177/2053951717753228

Pratt, Mary Louise (2008 [1992]). Imperial Eyes. Travel Writing and Transculturation. 2nd edition. Lontoo: Routledge.

Pöyhtäri, Reeta; Haara, Paula \& Raittila, Pentti (2013). Vihapuhe sananvapautta kaventamassa. Tampere: Tampere University Press. 
Reader, Bill (2012). Free press vs. free speech? The rhetoric of "civility" in regard to anonymous online comments. Journalism and Mass Communication Quarterly 89:3, 495-513. https://doi.org/10.1177/1077699012447923

Renninger, Bryce J. (2015). "Where I can be myself... where I can speak my mind": Networked counterpublics in a polymedia environment. New Media Q Society 17:9, 1513-1529. https://doi.org/10.1177/1461444814530095

Rheingold, Howard (1993). The Virtual Community. Massachusetts: Addison-Wesley Publishing Company.

Rheingold, Howard (2008 [1987]). Virtual communities - exchanging ideas through computer bulletin boards. Journal of Virtual Worlds Research 1:1. (Aiemmin julkaistu: Whole Earth Review, winter 1987.) Saatavilla: https://journals.tdl.org/jvwr/index.php/jvwr/article/view/293/247 (Luettu 25.8.2017).

Ridell, Seija; Kymäläinen Päivi \& Nyyssönen, Timo (2009). Julkinen tila tänään - kuhinaa lomittuvilla rajapinnoilla. Teoksessa: Ridell, Seija; Kymäläinen Päivi \& Nyyssönen, Timo: Julkisen tilan poetiikkaa ja politiikkaa. Tieteidenvälisiä otteita vallasta kaupunki-, media ja virtuaalitiloissa. Tampere: Tampere University Press, 7-38.

Ridell, Seija (2011). Elämää Facebookin ihmemaassa. Sosiaalinen verkostosivusto käyttäjiensä kokemana. Tampereen yliopisto, Viestinnän, median ja teatterin yksikkö CMT: Tampereen yliopistopaino.

Rowe, Ian (2015). Civility 2.0: a comparative analysis of incivility in online political discussion. Information, Communication Q Society 18:2, 121-138. https://doi.org/10.1080/1369118X.2014.940365

Seppänen, Janne \& Väliverronen, Esa (2013). Mediayhteiskunta. 2. painos. Tampere: Vastapaino.

Sobkowicz, Pawel \& Sobkowicz, Antoni (2012). Two-year study of emotion and communication patterns in a highly polarized political discussion forum. Social Science Computer Review 30:4, 448-469. https:// doi.org/10.1177/0894439312436512

Sunstein, Cass R. (2001). Republic.com. Princeton \& Oxford: Princeton University Press.

Suominen, Jaakko (2013). Lopuksi - sosiaalisen median nousut ja tuhot. Teoksessa: Suominen, Jaakko; Saarikoski, Petri; Turtiainen, Riikka \& Östman, Sari (toim.) Sosiaalisen median lyhyt historia. Helsinki: Gaudeamus, 287-293.

Svensson, Jakob (2015). Participation as a pastime: Political discussion in a queer community online. Javnost - The Public 22:3, 283-297. https://doi.org/10.1080/13183222.2015.1060014

Vainikka, Eliisa (tulossa). The anti-social network: Life politics in online conversation of the socially withdrawn. 